\title{
The Differentiated Parent Support Model: Enhancing the Involvement of Parents Who Do Not Speak the School Language
}

Mary MacPhee

University of Prince Edward Island

\begin{abstract}
Despite 40 years of research indicating that parent involvement is important for student achievement, schools have done little to engage parents across Canada. This study and model recommend strategies to enhance the probability of educational involvement for parents who do not speak the school language. The mixed methods research with surveys $(N=86)$ and interviews $(N=38)$ identified the successes and challenges of non-francophone parents with children in French minority-language schools. Parents wanted to help but struggled with French schoolwork and school-community involvement. Parents' low French proficiency and low school effort to facilitate parent communication and comprehension were some of the barriers that led to a decreased sense of parent autonomy and competency. Policy and practices by educators and parent-groups can encourage involvement and support parents in a French minority-language population as they overcome language
\end{abstract}

Canadian Journal of Education / Revue canadienne de l'éducation 44:1 (2021)

CO2021 Canadian Society for the Study of Education/ Société canadienne pour l'étude de l'éducation 
and insecurity barriers at home or school. The findings can be generalized to support parent involvement in other multilingual contexts.

Keywords: parent involvement, minority-language education, French minority language, differentiated parent support model, enhancing parent engagement

\section{Résumé}

Malgré 40 ans de recherche indiquant l'importance de l'implication parentale pour la réussite des élèves, les écoles canadiennes ont peu fait pour encourager la participation des parents. Cette étude ainsi que le modèle proposé recommandent des stratégies pour accroître la probabilité de l'engagement scolaire des parents qui ne parlent pas la langue de l'école de leur enfant. La recherche par méthodes mixtes avec sondages $(N=86)$ et entrevues $(N=38)$ a permis d'identifier les réussites et les défis de parents non francophones ayant des enfants dans des écoles de langue française minoritaires. Les parents voulaient aider, mais éprouvaient des difficultés avec les travaux scolaires et l'implication dans les activités scolaires et communautaires en français. La faible maîtrise du français des parents et le peu d'efforts de la part de l'école pour faciliter la communication et la compréhension des parents sont quelques-uns des obstacles qui ont conduit à une diminution du sentiment d'autonomie et de compétence des parents. Différentes politiques et pratiques des éducateurs et des groupes de parents peuvent encourager la participation et soutenir les parents dans un contexte français minoritaire dans leurs efforts pour surmonter les barrières linguistiques et l'insécurité à la maison ou à l'école. Les résultats de cette étude peuvent être généralisés pour soutenir l'implication parentale dans d'autres contextes multilingues.

Mots-clés : engagement des parents, écoles de langue françaises minoritaires, modèle de soutien différencié pour les parents, engagement des parents non francophones 


\section{Definition of Terminology}

NF parents (non-francophone parents) are defined for the purposes of this article by right-holder parent eligibility, thus, is someone who (a) does not have French as the first language learned and still understood, and (b) has not received their primary school instruction in Canada in a French school.

PI (parent involvement) is the educationally focused parent actions or interactions at home, at school, or in the community for the child's academic or French linguistic and cultural benefit.

ACB (autonomy, competence, and belonging) terms are borrowed from self-determination theory (Ryan \& Deci, 2000) about the motivation of individuals to commit to do something.

SED (self-determination and ethno-linguistic development model) is a model that includes the feelings of autonomy, competence, and belonging (ACB) (Landry et al., 2007b), which, among other factors, affect an individual's motivation and choice to learn or use a minority language. 


\section{Introduction}

Parents play a significant role in the academic success of students. However, many parents may not speak the dominant language of the child's school. In Canada, as a result of national legislation, French minority-language schools have been supported and expanded since the 1980s to offer education in French as a first language in provinces/territories where French is a minority-language. French minority-language schools are seen as vital components to fostering the maintenance and survival of the French language and culture and for helping minority French communities thrive and maintain identity and vitality (Arsenault-Cameron v. Prince Edward Island, 2000; Fishman, 1991; Landry, 2010; Landry \& Rousselle, 2003; Martel, 2001). The importance of parent involvement is especially significant in the French minority-language schools as a result of the Mahé v. Alberta case in 1990 (Mahé v. Alberta, 1990; Rocque, 2008). The precedent setting Mahé case determined that minority-language parents, rather than government officials, are responsible for the governance of the schools. It was and remains significant that the minority-language parents and right-holders would have a better understanding of how best to support the minority than government officials, who may lack the lived experience and linguistic understanding. Demographically, there is a growing linguistic diversity in French minority-language schools, and an increasing number of parents in French schools are not French-proficient. In the last decade, statistics showed that $64 \%$ of students in French schools had parents who were in exogamous couples, meaning one parent did not speak French (Landry, 2010) and indicating a large number of anglophone or allophone parents. This article draws on recent dissertation research that explored the involvement and role of the non-francophone (NF) parents in the children's education (MacPhee, 2018).

\section{Need for Research to Understand Parent Experience}

The Canadian Charter of Rights and Freedoms (1982) established the criteria for the parents who are right-holders and eligible to send their children to a minority-language 
French school. ${ }^{1}$ However, even though the Charter defines parent eligibility to French minority-language schools, there are no rules that specify children or parents need to speak the French language. Some right-holder parents do not speak French for a variety of reasons, such as assimilation, or loss of the minority language. Also, many French school boards have broadened admission policies to consider applications from NF parents and children who are not eligible to choose minority-language schools (Rocque, 2008). Therefore, an increasing number of the students populating French schools speak little or no French when they arrive at school (Cormier, 2005; Cormier \& Lowe, 2010; Ontario Ministry of Education, 2009). Decades of research have shown that parent involvement (PI) is an important indicator of student achievement, socially and academically (Desforges \& Abouchaar, 2003; Eccles \& Harold, 1996; Epstein, 2011; Jeynes, 2003, 2007, 2010; McNeal, 2014). Thus, for optimal student success in a French academic environment, where a minority language needs to be supported and developed, it is crucial to understand the motivation, experience, involvement, and needs of NF parents and to identify strategies to overcome any challenges the parents face.

This article presents the differentiated parent support model that was created to fill a gap in the scholarly and professional literature about the types of NF parents and the barriers NF parents face relative to their involvement in Canadian minority-language French schools (MacPhee, 2018). The recommendations and the new model are meant to offer practical information and strategies to school professionals, educators, administration, and parent groups in a French minority-language context. More broadly, any parents and educators in regions, school boards, and schools experiencing linguistic diversity can benefit from the model, policies, and practices that are recommended. The recommendations are significant because although there is a general agreement in the research spanning the last 40 years that PI is very important, according to Hornby (2011), very little of this research has been applied in practice. This study is also important because

1 The criteria are as follow:

Minority-Language Educational Rights

23. (1) Citizens of Canada ( $a$ ) whose first language learned and still understood is that of the English or French linguistic minority population of the province in which they reside, or $(b)$ who have received their primary school instruction in Canada in English or French and reside in a province where the language in which they received that instruction is the language of the English or French linguistic minority population of the province, have the right to have their children receive primary and secondary school instruction in that language in that province. (Canadian Charter of Rights and Freedoms, 1982) 
it offers a unique model for understanding PI and applying practices and policies that enhance PI. Despite what seems to be an obvious need to have effective communication between educators and parents, little was shown in the literature to demonstrate efforts on the part of French minority-language schools to communicate with NF parents (Rocque, 2006, 2019). With a growing number of NF parents in French schools in Canada and increasingly multilingual classrooms around our globe, this research is both timely and necessary and the recommendations are easy to implement. This study considered the reality faced by NF parents using theoretical models and research from parent involvement in education and barriers to PI (Council of Ministers of Education, Canada, 2003; Desforges \& Abouchaar, 2003; Eccles \& Harold, 1996; Epstein, 2011; Hoover-Dempsey, 2011; Hornby, 2011; Hornby \& Lafaele, 2011; Jeynes, 2011b; Kavanagh \& Hickey, 2013) as well as theories of education and language revitalization and maintenance in French minority-language settings (Landry \& Allard, 1990; Landry et al., 2006, 2007b, 2009; Rocque, 2008).

\section{Parent Involvement}

Hornby's model for parent involvement (2011) is relevant in this context because it expands beyond other models such as Epstein's (2011) six types of PI. Hornby's model (2011) considered PI from two perspectives: the possible contributions parents can make at school and at home, as well as parent needs, which schools can address to enhance PI. Each of these two categories addresses four types and levels of involvement for all, most, many, and some parents. For example, according to Hornby's continuum, all parents need effective channels of communication between home and school. Most parents need meetings with school staff, and many parents can benefit from parent workshops and sessions to address parent needs. However, only some parents need extra support such as counselling, or meeting with other parents who share similar interests or concerns. Hornby's (2011) list of contributions that parents can make is a continuum. For example, all parents can share information about their children with educators, most parents are able to collaborate with teachers by helping with school work at home, many parents can be a helpful resource in the school (e.g., helping in the classroom, fundraising, or offering parent support), and some parents will participate in school meetings, parent committees, and policy discussions. Hornby's model (2011) is designed for bi-directional PI between 
home and school, and educators are reminded that (a) not all parents are equally equipped for educational involvement, and (b) to be flexible with their expectations of PI, due to the vast differences in the lives and abilities of parents.

\section{Minority-Language Education}

Landry and Allard's counterbalance model (1990) considers the important roles for the family, school, and community in language maintenance or revitalization in minority-language situations. The Self-determination and Ethno-linguistic Development Model (SED) is a complex model that examined many factors that affect the motivation to learn and use a minority-language. One section of the SED addressed the feelings of autonomy, competence, and belonging (ACB) (Landry et al., 2007b), which affect an individual's motivation and choice to learn or use a minority language. These three feelings have been transposed for this study as important components for involvement of the NF parent and their motivation for a child to attend and remain in a French minority-language school when the parent is not proficient in the French language. The ACB aspects were considered important because research has indicated that parents are more likely to be involved if they feel welcomed at the school as part of the community, and if they received school support (Pushor, 2013; Jeynes, 2011c).

Another important concept in this context is francité familio-scolaire, proposed and studied by Landry and Allard (1997) to describe the efforts made at home to value and promote French at home and at school. The need to help NF parents promote francité familio-scolaire would be greater than for francophones, who would be more likely to use the French language, access French media, and expose children regularly to French culture. The results from this study were analyzed according to the francité familio-scolaire efforts and described the motivation of parents for their school choice, showed their levels of PI, and identified to what degree parents were able to promote francité familio-scolaire.

The theory and models from PI research and the theories of language revitalization and maintenance in French minority-language settings were used to create tables and analyze the research results. The barriers to PI, also known as involvement determinants or involvement factors, were other aspects considered and used to analyze the results, and that also contributed to the new model and to policy and practice recommendations. 


\section{Barriers to Parent Involvement}

Recognition of the significance of PI barriers has increased in recent years, in part due to the increasing multicultural and multilingual diversity in classrooms around the globe (Edwards, 2011; Hornby, 2011; Paik, 2011). As a result, barriers to PI have been identified in minority contexts and where parents do not speak the language of the school (Hornby, 2011; Liu, 2016). Eccles and Harold (1996) identified general barriers to PI when they found that parents' time, energy, economic resources, familiarity with curriculum, confidence in ability to help (efficacy beliefs), attitudes about a parent's role at different ages (of the child), and prior negative experiences with school accounted for a decreased amount (or lack) of involvement in the child's educational process. Jeynes (2011b) added parent language, socioeconomic status, and conflict with educators as factors that decreased involvement. Hornby and Lafaele's (2011) list of obstacles to PI included a lack of invitations from school and a non-welcoming atmosphere at school. They also explained that many teachers believed that parents were somehow deficient or less able to help, and these attitudes deterred PI. If educators in French schools see the NF parent as somehow deficient because of the language barrier and chose not to engage the parent, that belief and lack of action on their part could lead to decreased PI.

Hoover-Dempsey (2011) and Hornby and Lafaele (2011) explained that parents tend not to be educationally engaged in situations where a parent does not believe in the importance or value of PI or in his or her ability to help. For example, parent beliefs caused a decrease in PI in the case of Irish immersion students where the parents believed they could not effectively help their children because they did not know Irish (Kavanaugh \& Hickey, 2013). Additionally, parents were less involved when they believed that it was the school's responsibility, rather than the parent's responsibility, to educate students (Hoover-Dempsey, 2011; Hornby \& Lafaele, 2011). Hornby (2011) summarized PI barriers into four broad categories: parent and family, child, parent-teacher, and societal factors, which informed the involvement determinants in the new model.

\section{Involvement Barriers in Minority Contexts}

Research done in Canada, the United States, the United Kingdom, and New Zealand describe minority parents as typically born outside the host country, and shows that they experience more barriers to PI than native-born parents (Hornby, 2011; Turney \& 
Kao, 2009). Minority parents have a greater need to feel welcomed, and they experience greater language disparity, making communication with the school challenging. Minority parents may also have greater work, income, transportation, and safety challenges (Edwards, 2011; Hornby, 2011; Turney \& Kao, 2009). The NF parents could be seen as minority parents, despite coming from the same region, due to the lack of language proficiency and the involvement barriers they face.

Research into PI has demonstrated that parents are not all equally equipped to be involved in the same types of PI (Hornby, 2011; Turney \& Kao, 2009). Paik (2011) and Liu (2016) recommended that teachers and schools invite minority and diverse parents to be involved in a wide variety of ways. Ideally, educators would get engaged with the school community, collaborate with parents, and use a parent liaison and translation to overcome language and cultural barriers in assorted ways, including for meetings, newsletters, and events. Schools could support parents by employing effective communication strategies, initiating parent liaisons, and informing parents about the importance of providing books and developing literacy at home (MacPhee, 2018).

Paik (2011) argued that we will continue to see diversity in schools, so it is necessary to collaborate at all levels to assist minority groups. Edwards (2011) agreed with Paik, recommending that school professionals reflect and differentiate for diverse parents to enable or enhance PI, in the same way that educators differentiate teaching for diverse student needs. In terms of language, Kavanaugh and Hickey (2013) found that the parents' lack of language proficiency was the most frequent PI barrier. Those parents required help from the school to know how to assist with education in a minority language and to trust that they were able to contribute as educational partners. Thus, it is important that educators not see NF parents as deficient, but rather as valuable partners they can help, who in turn can assist students. Studies (Landry \& Allard, 1997; Landry et al., 2006) also showed that if an exogamous couple (two different languages, i.e., one English and one French mother tongue) made efforts to promote francité (French use) at home, then the students from exogamous couples did as well, both academically and linguistically, as the children from francophone couples. Cummins (2012) reported that for immigrant parents in French schools, being Anglo-dominant is not a disadvantage if the parents supported literacy development in their maternal language. He cited studies showing there was a transfer of skill across language, such as reading comprehension, which occurred for bilinguals. Therefore, parents can support the development of a minority 
language, regardless of their proficiency, by providing books and learning resources and supporting literacy development in their own language, while modelling positive attitudes towards the language being learned (Cummins, 2000; Kavanaugh \& Hickey, 2013).

\section{Research Questions}

Attention has been paid to PI in many contexts; however, little information was available in the literature about the involvement or barriers to involvement for the NF parent with children in French schools (Cormier \& Lowe, 2010; Rocque, 2006). This research aimed to discover the different types of NF parents present, understand the NF parent experience, identify PI challenges, and offer strategies, policy suggestions, and practices to assist and enhance parent involvement. This research was guided by the following research questions:

1. What are the demographic characteristics and the beliefs of NF parents who have chosen a French minority-language school for their children?

2. What are the experiences of NF parents who have children in a French minority-language school?

3. How are NF parents involved in the education of their children at home, at school, and in the community?

The research questions were influenced by the research literature and the questions asked by other researchers in this domain. Dalley and Saint-Onge (2008) asserted a need for more research on mixed (exogamous) couples' choice of school, especially since the exogamous couples are increasing, and mixed couples are assumed to comprise the right-holder population who do not choose francophone schools. One of their suggestions for future research questions was: "What is the lived family reality for the inclusion of Anglo-dominant right-holders and their children, and is it done in an inclusive way?" (p. 140). Arsenault (2008) questioned if there were sufficient strategies in place to enable the involvement of anglophone right-holder parents in the schools while being true to the purpose of francophone schools, and whether parents get enough information when making their choice. She also wondered if there was linguistic and social network insecurity for anglophone parents. Others (Rocque, 2006; Rocque \& Taylor, 2011) recommended 
more research about how to help NF parents, how to make NF parents feel welcomed in schools, how to help them feel reassured about their school choices, and how to better equip parents to offer support at home for French language education. There was limited information about NF parents in existing research, thus the importance of this study due to the increasing number of exogamous couples and NF parents who chose French schools.

\section{Methodology and Methods}

A mixed methods convergent research design (Creswell, 2014) using an online survey, focus group, and individual interviews was used to understand the complex and multidimensional social experience of NF parents (Mason, 2006a; Teddlie \& Tashakkori, 2011). Purposive sampling was used to involve NF parents who had children in any of the six French minority-language schools in the province of Prince Edward Island (PEI), Canada. Data for this research was collected from an online survey $(N=86)$ and interviews with 38 NF parents. In total, there were 34 participants who partook in nine focus groups (Kreuger \& Casey, 2000; Patton, 2015; Fontana \& Frey, 2000; Onwuegbuzie et al., 2009) as well as four individuals who participated in individual interviews.

Qualitative analysis was completed using classical content analysis and constant comparison analysis (Leech \& Onwuegbuzie, 2008; Strauss \& Corbin as cited by Onwuegbuzie et al., 2009). Data were organized using NVivo (Ver11.0) (QSR International 2011) to isolate a priori codes from existing theory and literature, including involvement, beliefs, and motivation, and newly added categories and codes that emerged from the data. New codes included bilingualism, preschool, and relationships, among others. The codes and themes were common across the different focus groups. Quantitative data was collected using SurveyMonkey (Fluid Survey) and the analysis was conducted using SPSS version 22 to perform descriptive and inferential statistical analyses of the survey data (Vogt, 2007).

To answer Question 1, NF parent characteristics such as heritage, language proficiency, marital status, and education were analyzed along with NF parent beliefs from the survey and interview data. The content concerning parent beliefs from the qualitative data supplemented the quantitative data. To answer Questions 2 and 3 about the experiences 
and involvement of NF parents, the qualitative and quantitative data for all examples and references to NF parents' experiences and involvement were categorized and analyzed according to Hornby's (2011) eight forms of parental contributions and parent needs (sharing information, collaborating with teachers, acting as a resource, policy formation, channels of communication, liaison with school staff, parent education, and parent support). Barriers to PI that were revealed, and the recommendations parents made to address them, were recorded. Parents' comments about feelings and experiences were categorized into the $\mathrm{ACB}$, or feelings of autonomy, competence, and belonging, from the SED model (Landry et al., 2007b).

\section{Results}

The findings confirmed that the clientele in minority-language French schools in PEI is diverse. The NF parents $(n=86)$ who participated in the survey were between the ages of 27 and 63; 52 (60.5\%) were mothers, 32 (37.2\%) were fathers, and 2.3\% reported as other. Five of the 86 participants $(5.8 \%)$ were immigrants, and 81 (94.2\%) were Canadian citizens. The vast majority of parents $(85.6 \%)$ had a post-secondary education with a college diploma $(n=35)$, a university degree $(n=36)$, or a graduate or professional degree $(n=60)$. In contrast, 22 parents $(14.4 \%)$ had some college $(n=8)$, some university $(n=2)$ or a high school diploma $(n=12)$. In general, there was high socio-economic status, with high levels of post-secondary education and income. The family income as reported by $56.6 \%$ of participants was $\$ 100,000$ or more, while $23.6 \%$ reported between $\$ 50,000$ and $\$ 99,999,15.8 \%$ reported between $\$ 25,000$ and $\$ 49,999$, and 3.9\% reported a family income of less than $\$ 25,000$. High SES of parents who choose French schools is consistent with previous research (Cotnam, 2011) and the literature on school choice by exogamous couples. Social capital, education, and the socio-economic status of parents have been shown to be important indicators of school choice (Cotnam, 2011) along with a strong parent value for bilingualism (MacPhee, 2018).

Twenty-seven of the 86 parents (31.4\%) reported being anglophone in an exogamous couple with a francophone partner. Out of the 59 other parents, 45 (52.3\%) were anglophone in an Anglo-dominant couple, three (3.5\%) were allophone in a couple with a non-francophone partner, and 11 (12.8\%) were anglophone single parents. These findings 
are important because where prior research considered exogamous couples (Cormier \& Lowe, 2010; Rocque, 2006), the results here show there are many other NF parents besides those in mixed couples. The data reveal that approximately $80 \%$ had low French proficiency. Considering the different types of NF parents and many who do not have a francophone or French-proficient parent at home, it is clear that the parents need (and would appreciate) assistance with PI in a French school.

Question 2 about parent experiences and Question 3 about parent involvement were answered by reviewing the data from the survey and from the interviews. When compared with Hornby's (2011) eight types of PI as described in Table 1 below, only two of the eight types of PI were functioning effectively for NF parents involved in this study. Parents were able to have occasional meetings with educators, and they successfully shared information about the children in English with educators. However, parents were challenged in six areas, including finding effective channels of communication throughout the year, attending parent workshops, contributing as a resource person at the school, or participating as a member in school groups or parent committees. Despite the social capital provided by high education and financial income, these NF parents were still struggling.

\section{Table 1}

Comparison of Involvement by NF Parents with Hornby's Recommendations (MacPhee, 2018)

\begin{tabular}{ll|c}
\hline \multicolumn{1}{c|}{ Parent Needs } & Parent Experience \\
\hline $\begin{array}{l}\text { 1. } \\
\text { All parents need open channels of communication, such as } \\
\text { newsletters, calls, emails, or agendas. }\end{array}$ & Partial \\
\hline $\begin{array}{l}\text { 2. Most parents need to have meetings and discussions with } \\
\text { school teachers or administration as liaison. }\end{array}$ & Successful \\
\hline $\begin{array}{l}\text { 3. } \text { Many parents need parent education or workshops on topics } \\
\text { of interest to parents. }\end{array}$ & Little \\
\hline $\begin{array}{l}\text { 4. } \\
\text { Some parents need support such as counselling or parent } \\
\text { other parents. }\end{array}$ & Parent Experience \\
\hline $\begin{array}{l}\text { All parents contribute by sharing details about children, } \\
\text { strengths or struggles, preferences, and medical information. }\end{array}$ & Successful \\
\hline
\end{tabular}




\begin{tabular}{l|c}
\hline 2. $\begin{array}{l}\text { Most parents contribute by helping at home with school } \\
\text { work or with behaviour programs. }\end{array}$ & $\begin{array}{c}\text { Frequent with } \\
\text { difficulty }\end{array}$ \\
\hline 3. $\begin{array}{l}\text { Many parents contribute as a helpful resource at school, } \\
\text { helping in the classroom, fund-raising, or aiding other par- } \\
\text { ents. }\end{array}$ & Little \\
\hline 4. $\begin{array}{l}\text { Some parents contribute at school meetings, in parent } \\
\text { committees, and during policy discussions or parent support } \\
\text { groups. }\end{array}$ & Little \\
\hline
\end{tabular}

Parents felt their need to contribute information to the school was met because educators accepted their notes or comments in English. The parent need for occasional discussion was met because teachers would often conduct parent-teacher interviews in English for the NF parent. However, regular communication in French from the school to the home was not effective, given the parents' low French proficiency and difficulty reading messages sent home in French, and few or no opportunities for parent workshops or support were offered, unless in French. Further, the majority of NF parents felt they could not assist as a resource in school or in committee meetings due to limited French proficiency. The analyses revealed that the majority of NF parents experienced a decreased sense of autonomy, competence, and belonging.

Most NF parents struggled with autonomy. They were conflicted about the need to use English and ask for documents or conversations in English when the school had a French language policy. They faced challenges to understand or translate weekly school newsletters, French homework assignments, or math problems, which are often language-based word problems. Many parents reported that they were able to help at home, but their involvement required more effort and time than it would if the children were in English or French immersion programs, and most parents did not feel at ease about their involvement. Thus, most parents did not feel the autonomy needed to be involved at the French school or in the French community. The sense of autonomy was stronger for parents with high French proficiency and weaker for parents with low or no French proficiency, who felt challenged because they regularly faced PI barriers at home, at school, and in the community. The low sense of autonomy points to a need for educators to reach out to the NF parents to improve communication and provide strategies and resources to enhance their involvement. 
Although the participants valued PI, wanted to be involved, and believed that their involvement made a difference, at least half of them did not feel competent helping with reading and spelling in French. Many parents were concerned about their own low French comprehension, poor pronunciation, and absence of social connections with other parents, and felt they could not be effectively involved in the school and community contexts. Only seven (18.4\%) of the participants had French proficiency and felt competently involved. NF parents needed help to address a decreased sense of competency and assist their children in the home language, as well as strategies and resources to help in French. It would be useful for parents to know what skills can transfer between languages. For example, Cummins (2000, 2012) and Chernoff (2005) explained that parents could support language development if they developed literacy or numeracy in the home language, and this contributes to literacy in a second language because skills can transfer between languages. It would be helpful for teachers and parents to know this, and for many parents to receive recommendations from educators for resources such as applications for mobile devices or websites to provide assistance for students with French pronunciation and writing.

Many of the participants reported a decreased sense of belonging; some parents felt unwelcomed and marginalized because they were not francophone, and many felt that they wanted to be acknowledged, involved, and heard. Parents whose children attended a French childcare in the school community centre prior to beginning school were more likely to feel well situated. NF parents had the opportunity during daily drop-offs and pick-ups to meet many other francophone and NF parents and develop a sense of belonging, network, and support. Although the NF parent accounted for a large section of the parent body in the schools, the voice of parents without French was not actively sought or shared. Additionally, because of the French language policy in the school, most of the parents did not feel comfortable bringing their needs forward. The NF parents wanted to feel welcomed and wanted to develop relationships with other parents, which would enable them to share or discuss school-related information, ask questions, and to participate in school or community activities with an improved sense of belonging. Many parents did not attend school events with the children because they did not understand the invitations from school, while others felt socially uncomfortable when attending events where they did not know anyone else and they were not proficient in the language. 
Previous studies indicated that helping parents develop a sense of belonging to the community and feeling welcomed is an important factor in PI (Cotnam, 2011; Cormier \& Lowe, 2010; Jeynes, 2011b; Pushor, 2013; Ryan \& Deci, 2000). Educational professionals can use diverse methods and effective communication strategies to ensure invitations to school events are received by parents. They can offer occasional meetings with translation or in English (or the parents' language) where parents can receive information, network/socialize, and share challenges and resources or strategies that help improve PI while contributing to building a sense of community.

If educators welcome, accompany, and equip NF parents with information, resources, and strategies, parents can make choices to enhance the francité familio-scolaire. Family choices and actions to develop the French language have had a positive outcome on bilingual development, bilingual identity, and academics in French minority-language schools (Landry \& Allard, 1997; Landry et al., 2007a). It follows that attending to the ACB needs of the NF parent will enhance PI, help parents to make choices to support French at home, support their children in French education, encourage the use of French by children at the school, and help parents to be generally more knowledgeable about their role.

\section{Differentiated Parent Support Model}

According to Hornby (2011) there was a large, negative gap between the 40 years of research recommendations to help parents be involved, and what educators and schools actually do to support PI. Thus, the significance of these research findings is addressing a recognized gap in the literature to learn what was being done for PI and what was available to help educators support parents who are not proficient in the school language, and specifically in French minority-language schools. The data and the research literature indicated a need to create a new theoretical model to encourage educators to enhance PI. The differentiated parent support model is built on the theories in French minority-language education, the research about PI, and the involvement determinants that parents face that reduce PI, as well as the findings from these NF parent data. The model attempts to take into account the increasing linguistic and cultural diversity of parents. This new model presents a framework to encourage schools to offer differentiated support to parents to reduce barriers to PI and to welcome and support all parents, including those 
parents who are not proficient in the school language. The model takes into consideration numerous factors that impact PI, including different linguistic types of parents, types of involvement, differentiated support for parents to enhance French linguistic and identity development for students, teacher and administrative roles, and the importance of establishing a PI policy. This new model is presented in Figure 1, followed by discussion about how the combination of elements can promote PI and, in this case, also promote French linguistic and cultural vitality.

\section{Figure 1}

Differentiated Parent Support Model (MacPhee, 2018) inspired by the Counterbalance Model (Landry \& Allard, 1990)

\section{DIFFERENTIATED PARENT SUPPORT MODEL}

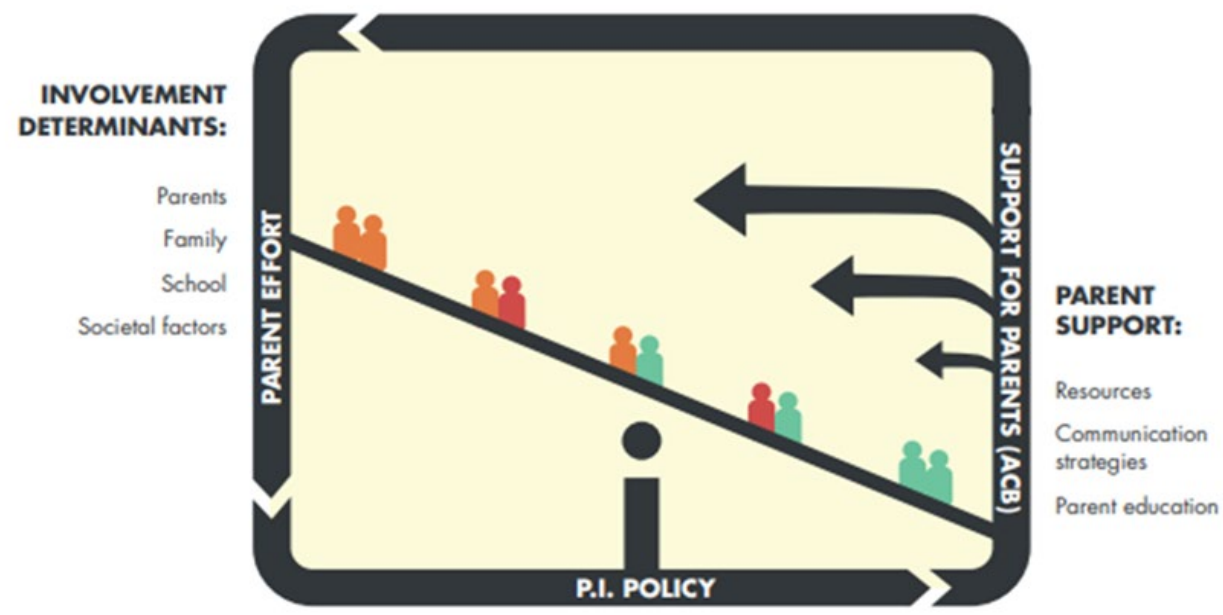

SCHOOL P.I. POLCY:

Encourages parent involvement \& gives support to balance needs

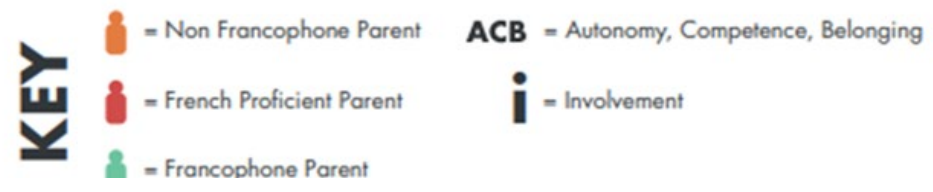

Note: Visuals of the model designed by John Fox 
The five types of parents, listed below, are aligned starting from the least French proficiency at the top of the list to the greatest French proficiency at the bottom. The bottom figures are assumed to have a greater degree of French proficiency, stronger francophone identity and cultural knowledge, and a familiarity with French schools and the francophone community.

- One or two parents, neither of whom have French proficiency

- Two NF parents, one of whom has French proficiency

- Exogamous couple with one francophone and one non-French proficient NF parent

- Couple with one francophone and one NF parent where both have French proficiency or a single NF parent with French proficiency

- Endogamous couple with two francophone parents or a single francophone parent

This differentiated parent support model (Figure 1) was developed after contemplating the theory of the counterbalance (Landry \& Allard, 1990) and SED models (Landry et al., 2007b). In the new model, the image of a balance beam is borrowed from the counterbalance model (Landry \& Allard, 1990). That model had, along with school and community, a family component, which did not take into account different types of parents outside of the exogamous (mixed language) family. This model includes families with varying levels of linguistic proficiency along the teeter-totter beam. The people figures represent a possible parent or couple on a continuum from francophone proficiency to no French proficiency. The model also represents the demographics in French minority-language education and Hornby’s (2011) model for parent involvement.

Parent involvement policy at the base. In the model (Figure 1), the long arrow along the base and curving upward on the right side represents the school and PI policy. The solid, thick base line indicates the implementation of a PI policy as a foundation at the school, which aims to encourage PI by attending to parent needs and encouraging parental contributions. The policy encompasses Hornby's (2011) eight actions to enhance PI, including the use of diverse strategies for effective school communication with parents, options for liaison between educators and parents, occasional parent workshops or support groups, and parents contributing information, collaborating at home, acting 
as a resource at school, and participating in committees and decision making at school. Schools would implement practices based on this policy to enable PI, using strategies to accommodate all parents, including those who are not proficient in the school language.

Resources to meet parent needs. On the right of the model (Figure 1), there are arrows that point left from the school toward the parents. These arrows indicate that educators help meet parent needs with appropriate resources, communication strategies, education, and support offered for parents. Likely there would be minimal school assistance and communication required by the French-proficient families who are situated lower down on the balance beam and who likely feel greater autonomy, competence, and belonging. This school support is indicated by a short, narrow arrow pointing from school to family. More (medium) support, in the form of additional resources and communication strategies, may be required for families higher up the beam, again with the assumption that less proficiency in French would be a barrier to involvement and feeling autonomy, competence, and belonging. This support is indicated by a medium-sized arrow pointing from school to families. Extra (high) school support, in the form of resources, communication strategies, and parent education or counselling is required for families at the top tier of this model, where French competency is limited or nonexistent. Some of the support for parents could be provided by other parents who share their contact information, or through monthly gatherings. The extra support indicated by the longest and widest arrow from school to family would strengthen NF parents' sense of autonomy, competence, and belonging.

Empower parents to feel autonomy, competence, and belonging. The letters ACB that appear with school support on the right side of the model (Figure 1) are borrowed from the SED model, where Landry et al. (2007b) spoke about the role of these basic feelings in developing an identity with a minority group and increasing the motivation to use a language. The ACB refers to a sense of autonomy, competence, and belonging that a school can help create for the parents as well as the students. Educators attending to these parent ACB feelings can help motivated parents to develop their identity as a member of the minority group and maintain their commitment to retaining their children in the French school system. If parents do not feel welcome and are unable to help their 
children, over time, frustration may result in removing their children from the school (Dalley \& St-Onge, 2008).

Flexible expectations for diverse involvement. There are many factors or involvement determinants that can reduce or impede PI. On the left side of the model (Figure 1), Hornby's (2011) four broad categories of involvement determinants or potential barriers, which could impact PI, are visible: parent and family factors, child factors, parent-teacher factors, and societal factors. The factors are displayed as determinants that affect PI as a reminder to educators to remain flexible with expectations held for parents and PI, because parents have differing capacities but can practice PI in diverse forms. From the data, the low French proficiency of NF parents created a language and communication barrier, limited autonomy, and limited feelings of competency, and fit in the category of parent and family factors. The decreased sense of belonging for NF parents at a French school would fall into parent-teacher and societal factors.

Parent effort to support students. Descending on the left side of the model (Figure 1) is a downward arrow that indicates the degree of support and actions required by parents to assist their child adequately in French minority-language education. The longer distance downward required by the non-French proficient parent indicates that a greater amount of effort is required from NF parents to be involved helping with homework, encouraging French outside of school hours, and participating at school and community events. It is important that this extra effort that is required from NF parents is recognized and acknowledged by educators (Cormier, 2015). Even without the language, these parents have already made a concerted effort by choosing French education. The French-proficient figures on the bottom of the beam symbolize those parents who likely invest less deliberate effort, since it is easier for French-proficient parents to help children with schoolwork and they may already be involved at school or in the French community. The greater involvement and participation from NF parents, resulting in the balance beam lowering down on the left, would balance the beam horizontally with their contribution to the school, committees, and community. These extra human resources from NF parents could reduce some of burden/lighten the workload for francophone parents and community groups, allowing the beam to move up on the right side toward greater balance and harmony. 


\section{Model Summary}

The differentiated parent support model provides a clear visual tool to demonstrate how parents who have less proficiency in the language of the school need more support from educators to meet their needs, to understand what is expected of them by the school, and to optimize their PI. By following the model and implementing the suggested PI policy and practices in French minority-language schools or other schools with linguistic diversity, educators can enhance PI. Further research may suggest how the model could be applied to other schools with linguistic diversity.

\section{Discussion}

Several practical recommendations for policies and practices arose from this research (MacPhee, 2018). These recommendations are intended to support school governance, administrators, and educators as they work to address PI barriers and enhance involvement of NF parents. First, schools and boards need to reconsider strict language policies that prohibit communication except in the school language. Parents are key participants in children's education and are valuable partners who can contribute to the school's mission. Diverse parents will be better able to support children in linguistic and academic achievement if they are informed in a language they understand about strategies and resources or when offered translation or tools to translate communication. Communicative practices could include newsletters, school notices, or permission forms in electronic versions or online in an easy-to-translate format or in two or more languages.

Second, parents can benefit from educators sharing the contact information of other parents who may be contacted for assistance by phone or in person. Finally, any burden for school personnel trying to translate or answer parent questions can be alleviated by pairing parents or offering several names of parent mentors for support when NF parents need to seek information or get help assisting with homework. When human and material resources are limited, engaging a larger number of members from the community of parents in a school will help achieve the school mandate and build bridges for improved communication, parent involvement, and student and school success.

These suggestions seem like common sense, yet they were not happening commonly in schools, even though they are important to implement to help parents. Educators 
and administration likely would benefit from professional development to consider the importance, the strategies, and the resources to promote PI. Educators conscious of parent needs and partnership potential could then support them with information about the transfer of skills from language development in the home language to the school language, and offer the above strategies such as pairing parents or recommending websites and applications to help with French at home.

In order for the NF parents to be key players in strengthening the students, school, and community in a minority-language context, the data indicate that parents need to be supported. Increased linguistic and cultural change is happening quickly and school classrooms are becoming diversified at a rate that makes it difficult for research to keep up. A productive way forward would be to invite the linguistically and culturally diverse members of the school into discussions and planning, so that the objectives of the schools and needs of families can be met with sensitivity and awareness.

\section{Conclusion}

Canadian French minority-language schools have appropriate policies and practices in place to maintain the minority-language school as a predominantly French space, given the need for a dedicated space for socialization and education in French. Integrating NF parents and students into French minority-language schools is indeed a delicate subject to discuss and address. Integrating NF parents and students means inviting the majority English language, not to mention other languages, into a space that was created to protect and maintain French and to assist the francophone community to grow. However, given the rapidly changing demographics and research data indicating a diverse clientele, including assimilated right-holders, the policies and practices should also welcome and integrate the NF parents and students they serve along with francophone parents and students, while prioritizing the French language.

Decades of poor or no access to French education contributed to assimilation and francophones who lost the language over several generations. Thus, providing French education and assisting those who are motivated to have their children reclaim the language are essential to maintain and revitalize the language and culture in minority contexts. 
The application of the knowledge gained from this research has great potential to enhance collaboration between French minority-language schools and NF parents, resulting in enriched learning situations for students, parents, and educators. Parent associations in the minority context will be better informed to help parents, especially NF parents, in the schools on Prince Edward Island and across Canada. Moreover, this research informs French language and cultural survival efforts to address linguistic, cultural, and social challenges in French minority contexts across Canada. The model and recommendations for policy and practice could be beneficial to enhance PI if generalized and applied more broadly in other contexts where parents do not speak the school language. 


\section{References}

Arsenault, L. (2008). Le choix de l'école Francophone par une famille exogame: exemple d'une approche sociolinguistique et ethnographique. In P. Dalley \& S. Roy (Eds.), Francophonie, minorités et pédagogie (pp. 259-280). Presses de 1'Université d'Ottawa.

Arsenault-Cameron v. Prince Edward Island, [2000] 1 SCR 3, 2000 SCC. https://scc-csc. lexum.com/scc-csc/scc-csc/en/item/1762/index.do

Canadian Charter of Rights and Freedoms, 23, Part I of the Constitution Act, 1982, being Schedule B to the Canada Act 1982 (UK), 1982, c 11.

Chernoff, E. (2005). Ways in which teachers may incorporate the cultural and social contributions of family into schools. In P. Ruggiano Schmidt (Ed.), Preparing educators to communicate and connect with families and communities (pp. 31-43). Information Age.

Cormier, M. (2005). La pédagogie en milieu minoritaire Francophone: une recension des écrits. Fédération canadienne des enseignantes et des enseignants. Institut canadien de recherche sur les minorités linguistiques. http://icrml.ca/images/ stories/documents/fr/cormier_marianne_recension.pdf

Cormier, M. (2015). Accueillir le majoritaire dans l'institution de la minorité? Minorités linguistiques et société/Linguistic Minorities and Society, 5, 100-121.

Cormier, M., \& Lowe, A. (2010). Étude de mesures d'accueil et d'accompagnement et de l'implantation de différents modèles d'intervention en francisation. Centre de Recherche et de Développement en Éducation.

Cotnam, M. (2011). Est-ce vraiment un «décrochage culturel»? Une analyse critique du concept de décrochage culturel à partir des écrits sur le choix scolaire des élèves en transition primaire-secondaire. Éducation, 6(2), 50-69.

Council of Ministers of Education, Canada. (2003). La francisation: parcours de formation. Projet pancanadien de français langue première à l'intention $d u$ personnel enseignant de la maternelle à la 2e année. Council of Ministers of Education, Canada. http://204.225.6.243/else/francisation/cd-rom/

Creswell, J. W. (2014). A concise introduction to mixed methods research. Sage. 
Cummins, J. (2000). Language, power and pedagogy: Bilingual children in the crossfire. Multilingual Matters.

Cummins, J. (2012). The intersection of cognitive and sociocultural factors in the development of reading comprehension among immigrant students. Reading and Writing, 25(8), 1973-1990.

Dalley, P., \& Saint-Onge, H. (2008). Choix scolaire des couples exogames au Yukon. Dans P. Dalley et S. Roy (Dir.), Francophonie, minorités et pédagogie (pp. 121142). Presses de l'Université d'Ottawa.

Desforges, C., \& Abouchaar, A. (2003). The impact of parental involvement, parental support and family education on pupil achievement and adjustment: Research Report 433. Department for Education and Skills.

Eccles, J. S., \& Harold, R. D. (1996). Family involvement in children's and adolescents' schooling. In A. Booth \& J. F. Dunn (Eds.), Family-school links: How do they affect education outcomes? (pp. 35-44). Erlbaum.

Edwards, P. A. (2011). Differentiating family supports. In S. Redding, M. Murphy, \& P. Sheley (Eds.), Handbook on family and community engagement (pp. 113-115). Information Age.

Epstein, J. L. (2011). School, family, and community partnerships: Preparing educators and improving schools (2nd ed.). Westview Press.

Fishman, J. A. (1991). Reversing language shift. Multilingual Matters.

Fontana, A., \& Frey, J. H. (2000). The interview: From structured questions to negotiated text. Handbook of Qualitative Research, 2(6), 645-672.

Hoover-Dempsey, K. (2011). Self-efficacy: Up to the challenge. In S. Redding, M. Murphy, \& P. Sheley (Eds.), Handbook on family and community engagement (pp. 61-68). Academic Development Institute.

Hornby, G. (2011). Parental involvement in childhood education: Building effective school-family partnerships. Springer.

Hornby, G., \& Lafaele, R. (2011). Barriers to parental involvement in education: An explanatory model. Educational Review, 63(1), 37-52. https://doi.org/10.1080/00 $\underline{131911.2010 .488049}$ 
Jeynes, W. (2003). A meta-analysis: The effects of parental involvement on minority children's academic achievement. Education \& Urban Society, 35(2), 202-218.

Jeynes, W. (2007). The relationship between parental involvement and urban secondary school student academic achievement: A meta-analysis. Urban Education, 42(1), $82-110$.

Jeynes, W. (2010). The salience of the subtle aspects of parental involvement and encouraging that involvement: Implications for school-based programs. Teachers College Record, 112(4), 747-774.

Jeynes, W. (2011a). Aspiration and expectation: Providing pathways to tomorrow. In S. Redding, M. Murphy, \& P. Sheley (Eds.), Handbook on family and community engagement (pp. 57-59). Information Age.

Jeynes, W. (2011b). Parental involvement and academic success. Routledge.

Jeynes, W. (2011c). Parental involvement research: Moving to the next level. The School Community Journal, 21(1), 9-18.

Kavanagh, L., \& Hickey, T. M. (2013). "You're looking at this different language and it freezes you out straight away": Identifying challenges to parental involvement among immersion parents. Language and Education, 27(5), 1-19. https://doi:10.1 $\underline{080 / 09500782.2012 .714388}$

Krueger, R. A., \& Casey, M. (2000). Focus groups: A practical guide for applied research (3rd ed.). Sage.

Lambert, W. E. (1973, November 15-16). Culture and language as factors in learning and education [Conference presentation]. The Fifth Western Symposium on Learning, Western Washington State College, Bellingham, Washington. http:// files.eric.ed.gov/fulltext/ED096820.pdf

Lambert, W. E. (1981). Bilingualism and language acquisition. Annals New York Academy of Sciences, 379, 9-22. https://doi:10.1111/j.1749-6632.1981.tb41993.x

Landry, R. (2010). Petite enfance et autonomie culturelle. Là où le nombre le justifie ...V. Institut Canadien de Recherche sur les Minorités Linguistiques.

Landry, R., \& Allard, R. (1990). Contact des langues et développement bilingue: un modèle macroscopique. The Canadian Modern Language Review/Revue 
Canadienne des Langues Vivantes, 46(3), 527-553. https://doi.org/10.3138/ cmlr.46.3.527

Landry, R., \& Allard, R. (1997). L'exogamie et le maintien de deux langues et de deux cultures: le rôle de la francité familio-scolaire. Revue des sciences de l'éducation, 23(3), 561-592. https://doi.org/10.7202/031952ar

Landry, R., Allard, R., \& Deveau, K. (2007a). Bilingual schooling of the Canadian francophone minority: A cultural autonomy model. International Journal of the Sociology of Language, 185, 133-162. https://doi.org/10.1515/IJSL.2007.029

Landry, R., Allard, R., \& Deveau, K. (2007b). A macroscopic intergroup approach to the study of ethnolinguistic development. International Journal of the Sociology of Language, 185, 225-253. https://doi.org/10.1515/IJSL.2007.032

Landry, R., Allard, R., \& Deveau, K. (2009). Self-determination and bilingualism. Theory and Research in Education, 7(2), 203-213. https://doi. org/10.1177/1477878509104325

Landry, R., Deveau, K., \& Allard, R. (2006). Vitalité ethnolinguistique et construction identitaire: Le cas de l'identité bilingue. Éducation et francophonie, 34(1), 54-81.

Landry, R., \& Rousselle, S. (2003). Éducation et droits collectifs. Au-delà de l'article 23 de la Charte. Éditions de la francophonie.

Leech, N. L., \& Onwuegbuzie, A. J. (2008). Qualitative data analysis: A compendium of techniques and a framework for selection for school psychology research and beyond. School Psychology Quarterly, 23(4), 587-604. https://doi. org/10.1037/1045-3830.23.4.587

Liu, H. Y. K. (2016). Economic immigrant parents' educational involvement in Prince Edward Island [Master's thesis, University of Prince Edward Island]. Island Scholar. https://www.islandscholar.ca/islandora/object/ir:21172

MacPhee, M. (2018). The experience of non-Francophone parents with children in minority-language French schools in Prince Edward Island: A mixed methods study [Doctoral dissertation, University of Prince Edward Island]. Island Scholar. https://islandscholar.ca/islandora/object/ir\%3A22514?solr nav\%5Bid \%5D=bc24b8a0c3381209993b\&solr_nav\%5Bpage $\% 5 \mathrm{D}=0 \&$ solr $\underline{\text { nav } \% 5 \text { Boffset } \% 5 \mathrm{D}=6}$ 
Mahé v. Alberta, [1990] 1 S.C.R. 342. https://scc-csc.lexum.com/scc-csc/scc-csc/fr/ item/580/index.do

Martel, A. (2001). Droits, écoles et communautés en milieu minoritaire, 1986-2002: analyse pour un aménagement du français par l'éducation. Commissariat aux langues officielles.

Mason, J. (2006a). Mixing methods in a qualitatively driven way. Qualitative Research, 6(1), 9-25. https://doi.org/10.1177/1468794106058866

McNeal, R. B., Jr. (2014). Parent involvement, academic achievement and the role of student attitudes and behaviors as mediators. Universal Journal of Educational Research, 2(8), 564-576. https://files.eric.ed.gov/fulltext/EJ1053945.pdf

Ontario Ministry of Education. (2009). Policy statement and guidelines on the admission, welcoming, and support of students in French-language schools in Ontario. http:// www.edu.gov.on.ca/eng/amenagement/admission.html

Onwuegbuzie, A. J., Dickinson, W. B., Leech, N. L., \& Zoran, A. G. (2009). A qualitative framework for collecting and analyzing data in focus group research. International Journal of Qualitative Methods, 8(3), 1-21.

Paik, S. J. (2011). Minority families and schooling. In S. Redding, M. Murphy, \& P. Sheley (Eds.), Handbook on family and community engagement (pp. 121-124). Information Age.

Patton, M. Q. (2015). Qualitative research and evaluation methods (4th ed.). Sage.

Pushor, D. (2013). Regulation or invitation? Creating safe and welcoming schools. Education Canada, 53(2), 39-41.

Rocque, J. (2019). Increasing the English-language content on francophone minority school boards' websites in Canada: A longitudinal study (2008-2016) in support of non-French speaking parents and guardians. Revue des sciences de l'Éducation de McGill, 54(3), 542-565. https://doi.org/10.7202/1069769ar

Rocque, J. (2008). La vitalité des écoles de la langue française en milieu Francophone minoritaire: Droit fondé sur les luttes du passé. Le point en administration de l'éducation, 11(2), 36-39. 
Rocque, J. (2006). L'éducation en français langue première: étude sur le phénomène de l'exogamie et de la gestion scolaire en milieu minoritaire: une étude de cas du conseil scolaire Centre-Est de l'Alberta (Unpublished doctoral dissertation). Université Laval, Sainte Foy, QC.

Rocque, J., \& Taylor, G. (2011). La participation de couples mixtes à la gestion scolaire Francophone. In J. Rocque (Ed.), La direction d'école et le leadership pédagogique en milieu Francophone minoritaire: considérations théoriques pour une pratique éclairé (pp. 191-218). Presses universitaires de Saint-Boniface.

Ryan, R. M., \& Deci, E. L. (2000). Self-determination theory and the facilitation of intrinsic motivation, social development, and well-being. American Psychologist, 55(1), 68-78. https://doi.org/10.1037/0003-066X.55.1.68

Teddlie, C., \& Tashakkori, A. (2011). Mixed methods research: Contemporary issues in an emerging field. In N. K. Denzin \& Y. S. Lincoln (Eds.), Handbook of qualitative research (4th ed., pp. 285-300). Sage.

Turney, K., \& Kao, G. (2009). Barriers to school involvement: Are immigrant parents disadvantaged? The Journal of Educational Research, 102(4), 257-271. https:// doi.org/10.3200/JOER.102.4.257-271

Vogt, P. (2007). Quantitative research methods for professionals. Pearson. 